\title{
Coupling of Boronic Acids, 1,3-Enynes and Cyclic Imines
}
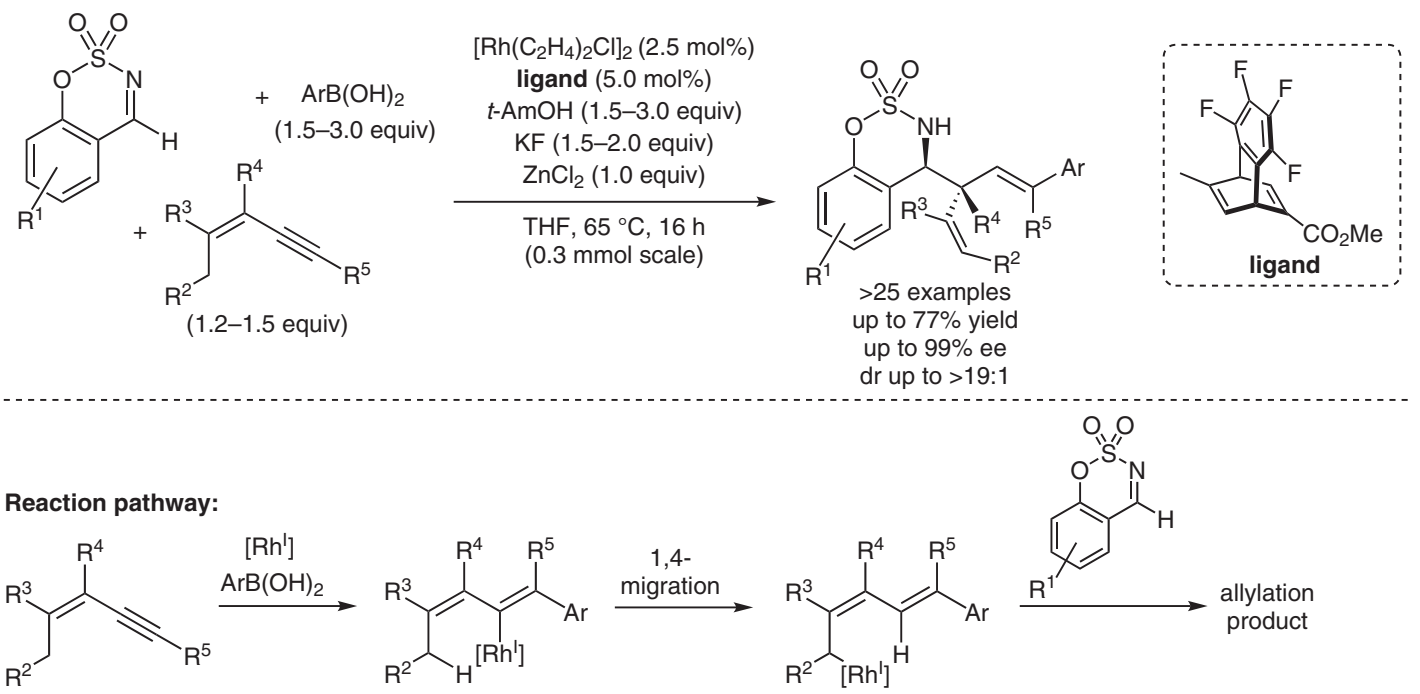

Selected examples:<smiles>C=C(C)[C@H]1C/C(=C\C(CCc2ccccc2)c2ccccc2)C(C)c2cc(Br)ccc2O1</smiles>

$70 \%$ yield, $99 \%$ ee, $\mathrm{dr}>19:$<smiles>O=S1(=O)N[C@H]([C@H](/C=C\OCc2ccccc2)c2ccccc2)c2ccccc2O1</smiles>

$66 \%$ yield, $69 \%$ ee, $d r>19: 1$<smiles>C=C(C)C(/C=C(\CCc1ccccc1)c1ccccc1)C1NS(=O)(=O)Oc2cc3c(cc21)OCO3</smiles>

$52 \%$ yield, $99 \%$ ee, $d r>19: 1$<smiles>[R5]CC/C(=C\[C@@H](C(=C)C)[C@H]1NS(=O)(=O)Oc2ccccc21)c1ccccc1</smiles>

$46 \%$ yield, $99 \%$ ee, $d r>19: 1$<smiles>C=C(CCC=C(C)C)[C@H](/C=C(\C)c1ccccc1)[C@H]1NS(=O)(=O)Oc2ccccc21</smiles>

$53 \%$ yield, $99 \%$ ee, $d r>19: 1$<smiles>C=C(C)[C@H](/C=C(\CCc1ccccc1)c1ccccc1F)[C@@H]1NS(=O)(=O)Oc2ccccc21</smiles>

$68 \%$ yield, $98 \%$ ee, $d r>19: 1$

\section{Key words}

rhodium catalysis

enantioselective nucleophilic allylation

1,4-rhodium(I) migration

three-component coupling
Significance: The authors describe a rhodiumcatalyzed highly stereoselective coupling of arylboronic acids, 1,3-enynes and cyclic imines. The key step is an alkenyl-to-allyl 1,4-Rh(l) migration, which leads to enantioselective allylation with the cyclic imine. Given the number of alternative pathways, the chemoselectivity of this method is notable.

SYNFACTS Contributors: Mark Lautens, Tamara Beisel

Synfacts 2018, 14(02), 0149 Published online: 18.01.2018 Dol: 10.1055/s-0036-1591015; Reg-No.: L16917SF
Comment: Deuterium-labeling experiments suggest that the 1,4-Rh(I) migration occurs by $\mathrm{C}-\mathrm{H}$ oxidative addition to give a $\mathrm{Rh}$ (III) hydride, followed by $\mathrm{C}-\mathrm{H}$ reductive elimination. Use of $\mathrm{ZnCl}_{2}$ gave more consistent results. The authors suggest an acceleration of the allylation by Lewis acid activation or improvement of catalyst turnover. 